\author{
А.Е. Поляков \\ (Россия, Москва) \\ pollex@mail.ru
}

\title{
ОРФОГРАФИЯ ОСТРОЖСКОЙ БИБЛИИ В КОНТЕКСТЕ ЦЕРКОВНОСЛАВЯНСКОГО КОРПУСА*
}

Современная церковнославянская орфография достаточно стандартизирована и четко фиксирует правила употребления букв и диакритических знаков, использование сокращений (титл и буквотитл), правила словоделения, правила написания конкретных словоформ и различения омонимов. Наличие такой нормы позволило нам создать грамматический словарь и морфологический анализатор для церковнославянского языка (http:/dic.feb-web.ru/slavonic/dicgram/ index.htm), который используется в корпусе церковнославянских текстов (http:// ruscorpora.ru/search-orthlib.html). Острожская Библия 1581 года, как первое полное издание Библии на церковнославянском языке, также должна быть включена в корпус, но при этом возникла масса проблем. Орфография этого издания сильно отклоняется от современной нормы и отличается крайней нерегулярностью и нестабильностью. В данной статье анализируются орфографические особенности Острожской Библии и возможность ее автоматического морфологического анализа. Специально рассматриваются правила употребления дублетных букв и других графических средств, которые порождают массу вариантов написания для конкретного слова. В результате делается вывод о том, что морфологический анализатор должен быть существенно переделан, чтобы он мог обрабатывать тексты в старой орфографии, а также определяются направления дальнейшей работы.

Ключевые слова: церковнославянский язык, орфография, корпусная лингвистика, автоматический морфологический анализ

* Работа выполнена при поддержке РФФИ, проект № 17-04-12064-ОГН «Разработка модулей НКРЯ для автоматической разметки и словарной поддержки старорусских и церковнославянских текстов». 


\section{1. Введение}

Современная церковнославянская орфографическая норма сложилась к концу XVII-го века и была зафиксирована в ряде фундаментальных изданий, таких как Грамматика Смотрицкого (издание 1648 года) и Елизаветинская Библия (1751 год). Эта норма достаточно четко фиксирует правила употребления букв и диакритических знаков, использование сокращений (титл и буквотитл), правила словоделения, правила написания конкретных словоформ и правила различения омонимов. Грамматические омонимы различаются при помощи дублетных букв (моєго́-моєгі́,

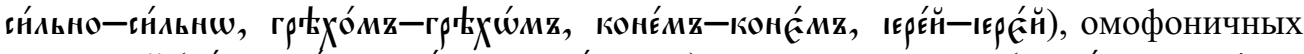
сочетаний (на́ша-на́шА, на́шнмz-на́шымz) и знаков ударения (кАаги́мz-благи̂мz,

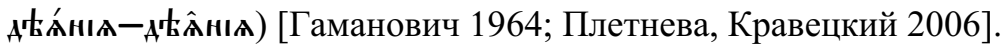

Наличие орфографической нормы позволило нам создать грамматический словарь и морфологический анализатор для церковнославянского языка (http:/dic. feb-web.ru/slavonic/dicgram/index.htm), который используется в корпусе церковнославянских текстов (http://ruscorpora.ru/search-orthlib.html) [Поляков 2014; Поляков 2017; Добрушина, Кравецкий, Поляков 2015]. Морфологический анализатор достаточно толерантен к ошибкам и умеет унифицировать мелкие графические различия $(\mathrm{O}-\mathrm{O}, \mathrm{E}-\mathrm{C}, \mathrm{O}-\mathrm{V}, \mathrm{b}-$ паерок, придыхания). Однако он не может игнорировать смыслоразличительные противопоставления, которых требует современная орфографическая норма $(\mathrm{V}-\mathrm{I}-\mathrm{V}, \mathrm{O}-\mathrm{G}, 3-\mathrm{S}, \Phi-\Theta$, ударения, сокращения, словоделение).

Включение в корпус текстов, изданных до середины XVII-го века, вызывает массу проблем, поскольку старая церковнославянская орфография заметно отличается от современной нормы, а также крайне нерегулярна и нестабильна, что типично для рукописной традиции и раннего периода книгопечатания. Одно и то же слово может писаться по-разному в зависимости от первоисточника, типографского удобства, аккуратности наборщика и других случайных факторов. Клитики обычно пишутся слитно с основным словом, а приставки иногда пишутся отдельно, дублетные буквы употребляются по-другому, правила различения омонимов не работают.

Морфологический анализатор, ориентированный на современную орфографию, не может нормально обрабатывать тексты в старой орфографии - многие слова не опознаются вообще или опознаются неправильно. Можно попытаться унифицировать все возможные графические варианты, но тогда нам будет трудно различить омонимы и даже отличить сокращенное написание от полного. Проблема слитного написания вообще не решается обычными методами.

Острожская Библия, изданная Иваном Федоровым в 1581 году в Остроге первое полное издание Библии на церковнославянском языке. Орфография этого издания сильно отклоняется от современной нормы и отличается чрезвычайной свободой и непоследовательностью. В данной статье мы рассмотрим орфографические особенности Острожской Библии с целью выработки правил для морфологического анализатора. 


\section{2. Источники текста}

Острожская Библия была подготовлена в текстовом виде благодаря усилиям автора и отдана в общее пользование в качестве открытого интернет-ресурса, который доступен по адресу: http:/dic.feb-web.ru/slavonic/corpus/0/bible1581/index.htm.

Электронный текст подготовлен на основе следующих источников:

1) Факсимильная (отсканированная) копия Острожской Библии [ОБ факсимиле].

2) Острожская Библия: современный набор с параллельным переводом на украинский язык. Подготовил Рафаил (Роман) Торконяк [ОБ 2006].

Факсимильная копия сама по себе не может заменить текстовый корпус, поэтому в качестве основного был выбран текстовый набор Торконяка, несмотря на то, что он не является точным воспроизведением оригинала. Так, в оригинале клитики пишутся слитно с основным словом, а в тексте они отделены пробелами согласно

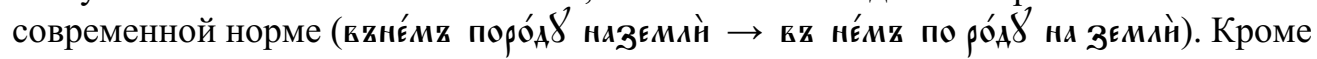
того, там есть отдельные опечатки и отклонения от оригинала, которые мы постарались исправить при возможности. Однако мы сохранили раздельное написание клитик, поскольку это необходимо для работы анализатора и поиска в корпусе.

Кодировка текста была приведена в соответствие с современным стандартом «Church Slavonic typography in Unicode» [Unicode TN41], насколько это возможно. Дело в том, что типографика Острожской Библии устроена весьма сложно, а ее интерпретация неоднозначна и допускает различные толкования. Например, в оригинале камора визуально практически неотличима от придыхания, поэтому нам пришлось восстанавливать это различие на основании теоретических правил, а не реального текста (см. п. 6).

Для улучшения читаемости текста были сделаны некоторые упрощения при передаче символов, которые отсутствуют в стандартном наборе, чтобы пользователь мог видеть текст без установки специальных шрифтов. В частности, в данной

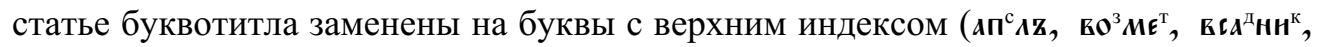
e $\left.\mathbf{v}^{\mathrm{T}} \boldsymbol{\Lambda} \mathbf{E}, \mathbf{3}^{\mathrm{M}} \mathbf{H h l}^{\mathrm{x}}\right)$, а придыхания воспроизводятся только в разделе 6.2 , специально посвященном этому вопросу. Далее мы часто будем давать примеры в несколько упрощенном виде, что, впрочем, никак не влияет на результаты анализа.

\section{3. Общая характеристика графико-орфографической системы}

Основной особенностью средневековой кириллической графики является наличие большого числа дублетных (омофоничных) букв, для которых нужно было придумать какие-то правила употребления [Карский 1979; Каверина 2010; Кусмауль 2014]. Любопытно сравнить эту ситуацию с латиницей, где, наоборот, букв было мало и для изображения недостающих фонем приходилось использовать диграфы (ch sh th gn nh $1 \mathrm{lh}$ ae oе ue) и надстрочные знаки (с̌ š ž ̃ ä ö ü).

В древнейшей кириллице были дублетные буквы И=I, О=Њ). В собственно славянских словах употреблялись в основном И О, буква I использовалась 


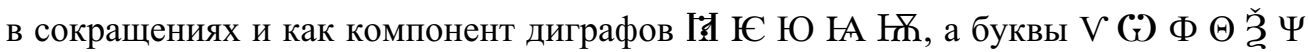
должны были использоваться только для греческих слов. Буква $\mathrm{V}$ первоначально произносилась как греческое [ӱ], но в результате фонетических изменений в самом греческом совпала с И=I=V. Буква $\Theta$ произносилась как [ф] или [т] в разных традициях, но в русском варианте совпала с $\Phi=\Theta$.

В русской кириллице за счет фонетических изменений появились новые пары дублетов I: $=\mathrm{FA}, \mathrm{Oy}=\mathrm{W}, \mathrm{O}=\mathrm{F}$, 3=S, затем вторые варианты фактически перестали употребляться на письме. Позже некоторые из этих букв были частично восстановлены как подражание южнославянским текстам, вместе с другими орфографическими особенностями.

В рукописной традиции появились графические варианты букв, не имеющие аналогов в древнейшей кириллице, например, $\mathcal{O}$ широкое-О узкое-О очное, $\mathcal{C}$ широкое-Е узкое, Oy-У, а также сложились некоторые правила их употребления. Например, О Є Оу обычно пишутся в начале слова или слога, тогда как О Е 学 в середине слова или слога (после согласной), но это правило нестрогое и часто нарушается (см. п. 4).

В древнейшей кириллице было четкое различие йотированных и простых гласных. Буквы І· Ю Ю НА Ю обозначали сочетания [й+гласная] или палатальность согласного (Зємлю, Зємлю, Зємлюк, Аюкнтн), тогда как нейотированные буквы $\mathrm{E}, \mathbf{A}$ обозначали просто (полу)мягкость согласного. В ходе эволюции русского письма это различие стерлось из-за фонетических изменений, в результате буквы $\mathbf{I}=\mathbf{A}, \mathfrak{€}=\mathrm{E}$ фактически стали дублетами - каждая из них могла обозначать сочетание [й+гласная] или палатализацию согласного. Прежнее различие частично сохранилось как контекстное правило - обычно If $Ґ / €$ пишутся в начале слова или слога, А Е в середине слова или слога, но это правило нестрогое и не всегда соблюдается (см. п. 4).

Ниже мы рассмотрим правила употребления отдельных букв и графических знаков в тексте Острожской Библии по сравнению с современной церковнославянской нормой. Основное внимание будет уделено графическим дублетам, которые создают массу вариантов написания для конкретного слова.

\section{4. Правила употребления отдельных букв}

\section{1. $U=I=V$}

В современном церковнославянском буквы И-І являются позиционными вариантами в славянских словах: I пишется перед гласным, И перед согласным или на конце слова. Противопоставление И-І используется для различения нескольких омонимов: ми́рz vs. мі́рz, кннó vs. кıна́. В греческих словах довольно четко соблюдается этимологическое различие И-I-V: ıсаи́кz Vs. нса́кz, ски́нїа Vs. єки́мєнz,

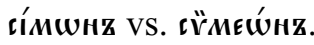

В Острожской Библии И достаточно регулярно заменяется на I перед гласной, в том числе на границе слов, которые в оригинале пишутся без пробела: І нз̆нєєે, 
I Овлада́нте, I tákи́сл, I ớcпe, I нзындо́ша. ВПрочем, перед гласной может также

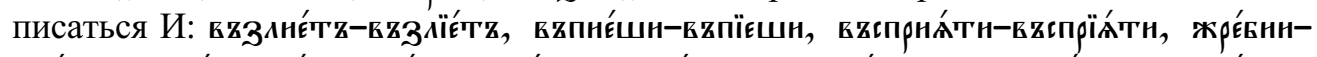

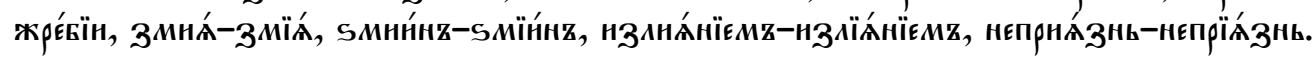

В греческих словах этимологическое различие I-И почти не соблюдается, при-

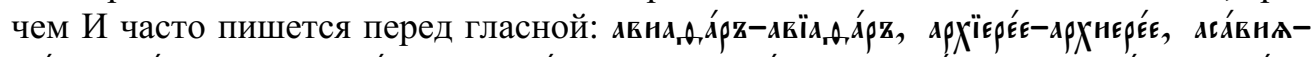

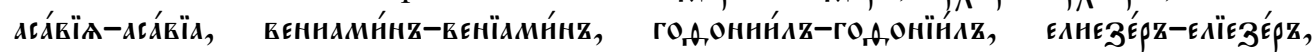

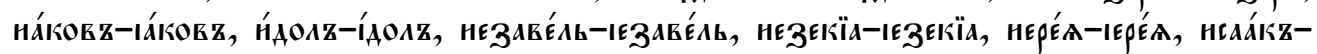

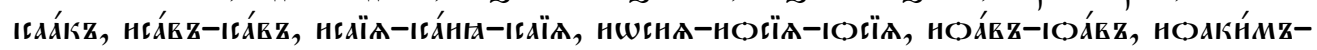

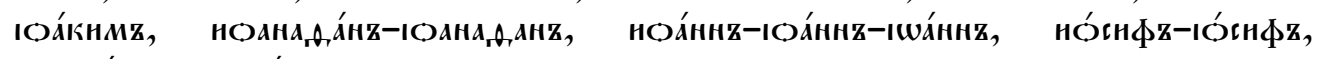
манаси́нна-манасі́нна.

Буква $\mathrm{V}$ регулярно пишется в следующих словах и их производных, иногда даже вместо этимологического правильного И (такие случаи помечены *): acŕpïa,

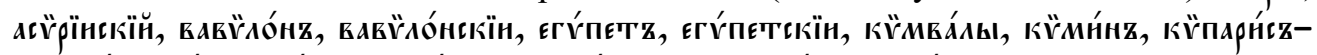

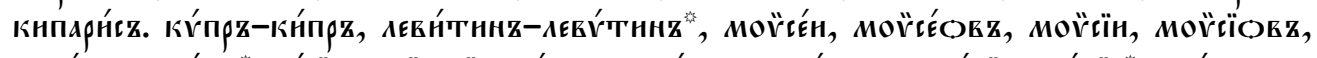

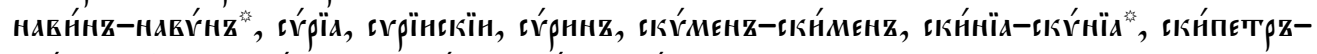

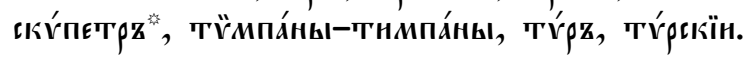

\section{2. $O=O=G$}

В современном церковнославянском $\mathrm{O}$ пишется только в начале слова, а также в начале корня в сложных словах (оте́цz, пра́отєцz).

В Острожской Библии О регулярно заменяется на $О$ в начале слова и сло-

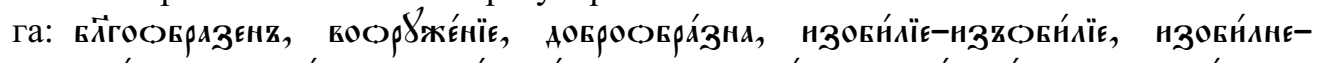

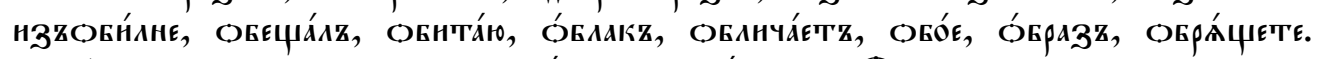
Особенно характерно слово нзоки́лїє-нзұови́лїє, где О пишется после немого Ђ, но меняется на О при его устранении.

Это правило соблюдается абсолютно четко и распространяется на грече-

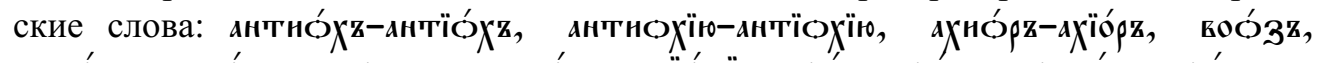

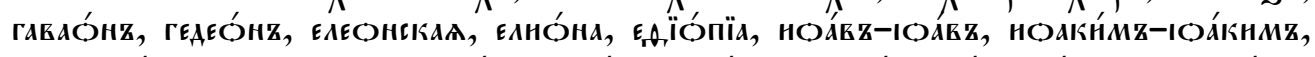

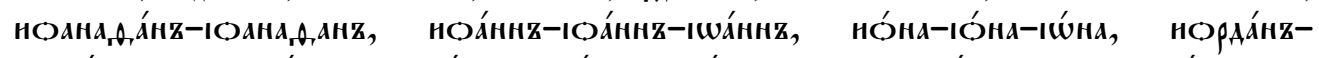
ІОра⿱䒑нz, нОсафа́тz-ІОсафа́тz, но́снфz-ІО́снфz, нскарно́тzскїн-нскарїо́тzскїн,

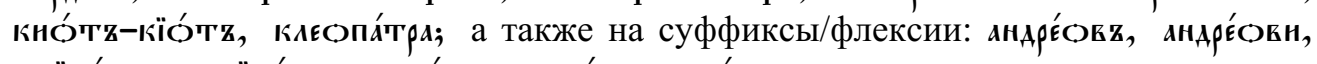

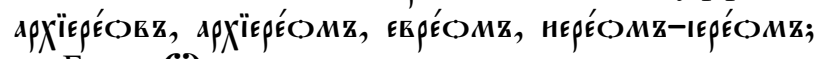

Буква (2) по первоначальному замыслу должна была использоваться для греческих слов, но в реальности она стала применяться в русских словах, обычно в составе лигатуры $\mathbf{\mathbf { C }}=\mathrm{OT}$.

В современном церковнославянском буква (2) используется в следующих случаях:

1) в греческих словах в соответствии с этимологией (ıша́ннz, íwzz, сі́мшнz);

2) в приставке $\boldsymbol{w}(\mathbf{\varepsilon})$-, особенно в глаголах (швнта́тн vs. Ови́тєль, швдача́тн vs.

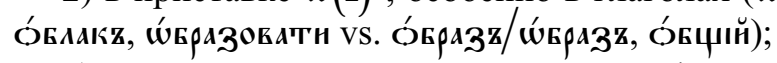

3) для различения грамматических форм (рабо́мz vs. рави́мmz, мн́логтн vs.

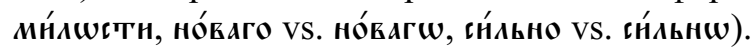




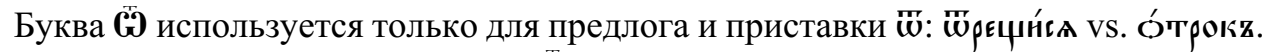

В Острожской Библии лигатура (⿱一) используется для предлога и приставки $\mathbb{W}$,

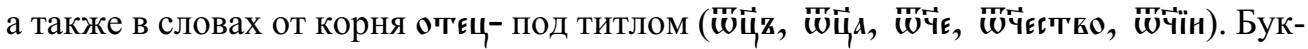
ва $($ используется крайне редко как эквивалент $\mathcal{O}$ в начале слова и слога, причем

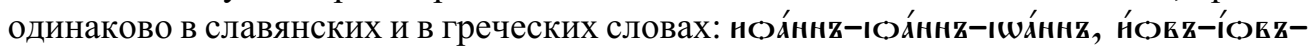

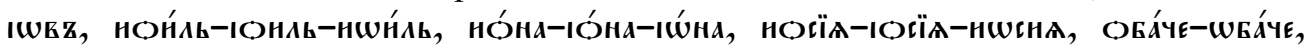

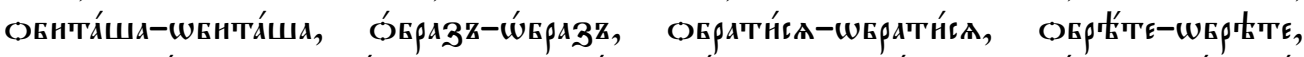

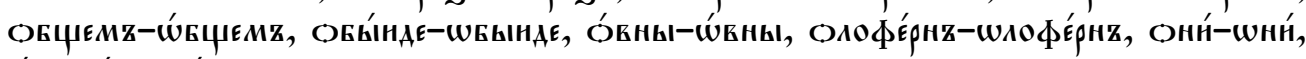
о́нz-ẃнz, о́троцы-штроцы, охозїл-шхозїА.

4.3. $\mathrm{H}=\mathrm{O}$.

В современном церковнославянском ми - Оу пишется в начале слова, а в середине заменяется на оу́мнай vs. вез

В Острожской Библии Уூ/Oy также являются позиционными вариантами и употребляются по тем же правилам, что $\mathrm{O} / \mathrm{O}-\mathrm{O}$ п пишется в начале сло-

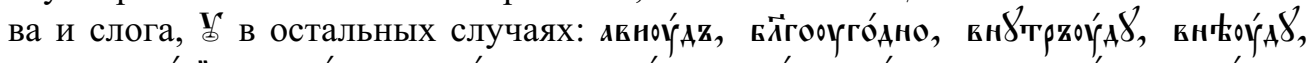

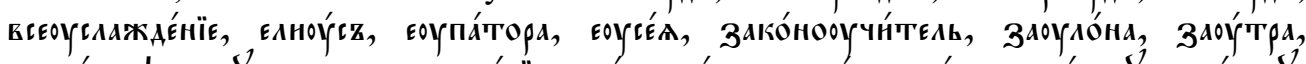

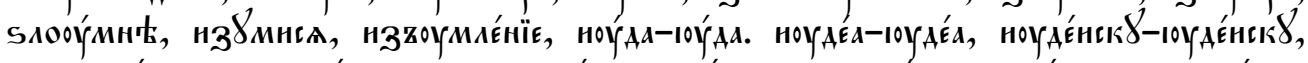

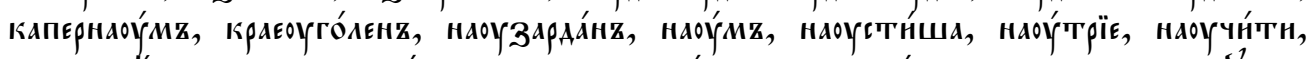

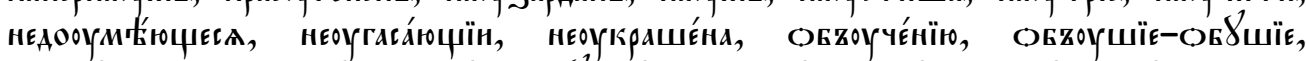

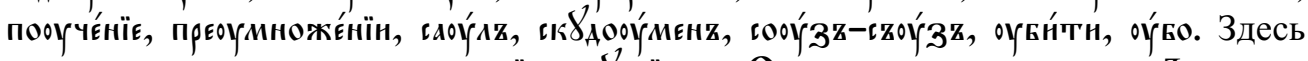
также характерно слово оввоушїє-ов४шїє, где ОУ пишется после немого Ђ, но меняется на У్ при его устранении.

\section{4. $E=C$}

В современном церковнославянском буква $€$ регулярно употребляется в начале слова, а также для различения грамматических форм единственного vs. множест-

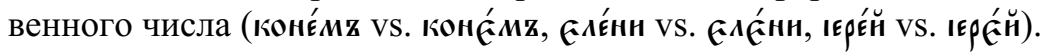

В Острожской Библии буква $C$ употребляется в единичных случаях как пол-

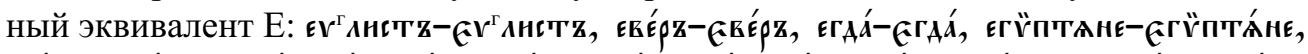

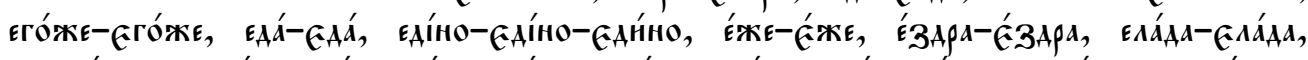

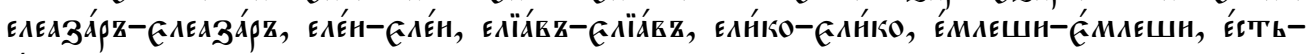
Écrts.

\section{5. $A=r$ H}

В современном церковнославянском 神/A являются позиционными варианта-

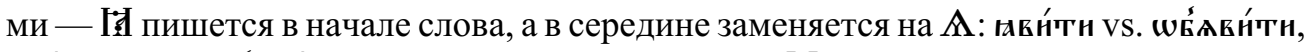

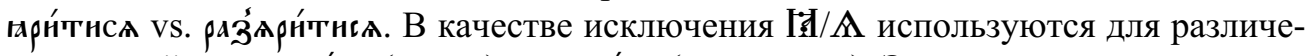
ния корней слов нзй́к- (народ) vs. Азй́к- (орган речи). Это различие явно введено искусственно и не очень удачно - с таким же успехом здесь могло использоваться различие 3 vs. S: вsќı- (народ) vs. нақи́к- (орган речи). 
В Острожской Библии буква I: практически регулярно пишется в начале сло-

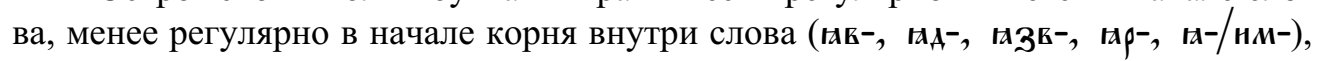
и крайне редко в начале слога внутри слова, где обычно пишется А. После согласных всегда пишется А. Вот примеры (редкие варианты помечены *):

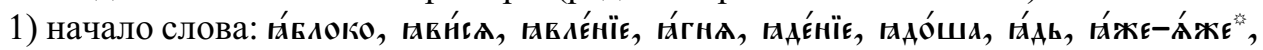

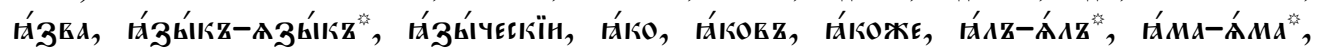

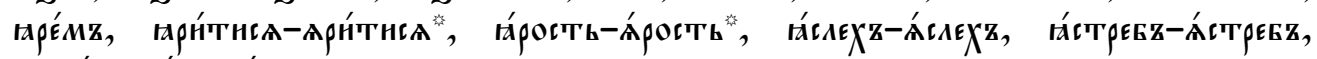
нчме́нь, Һа́ша-и́ша;

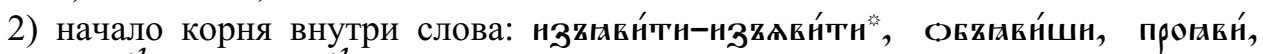

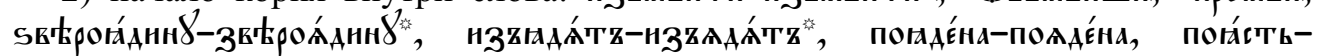

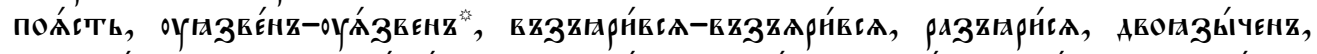

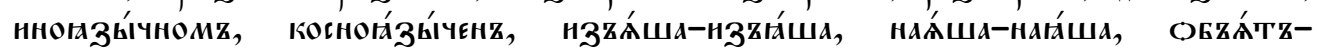

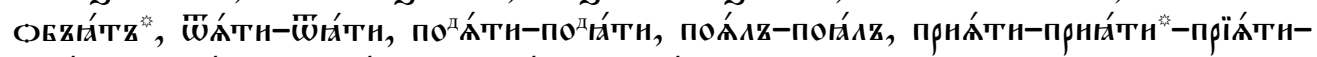

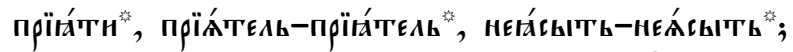

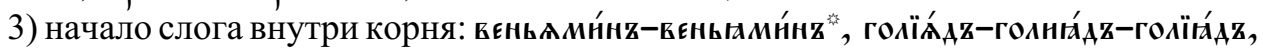

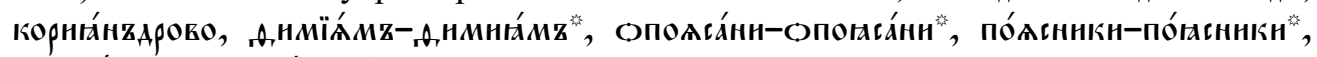
препои́санн-Препон́́санн ;

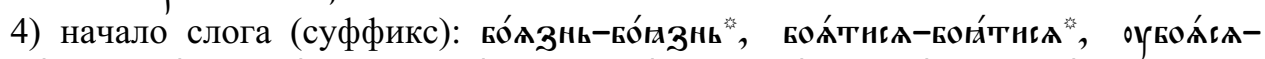

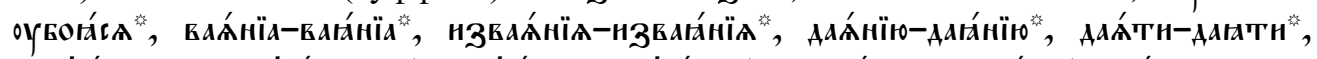

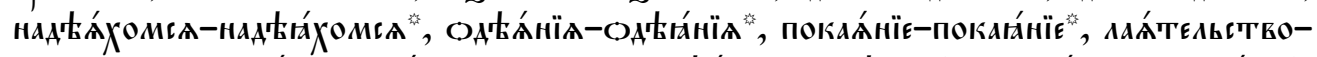

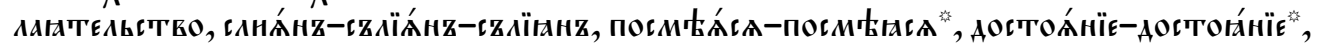

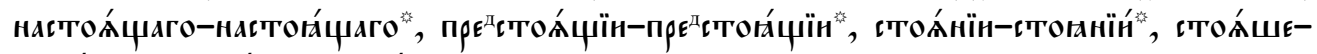

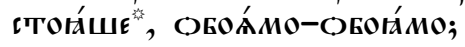

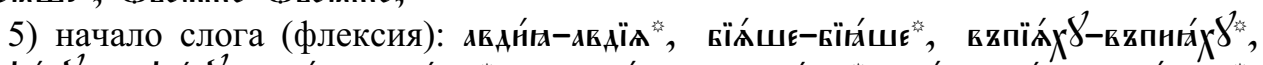

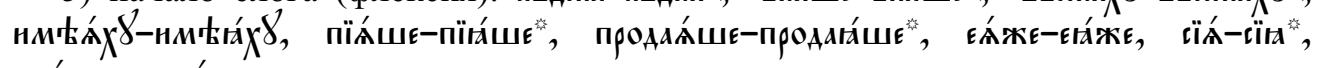
кои́жАО-кон́жАо.

Можно увидеть слабую попытку различить корни -ғА и -л/нм за счет Г: $/$ /A (пов́хz от поға́стн Vs. пох́хz от пои́тн), но для окончательного вывода слишком мало материала.

\section{6. $\Phi=\Theta$}

В современном церковнославянском $Ф$ и $\Theta$ обычно употребляются правильно в соответствии с этимологией, особенно для частотных и известных слов (кн,, Ає́́мz), а ошибки встречаются в редких и малоизвестных словах.

В Острожской Библии Ф и $\Theta$ также употребляются довольно правильно в соответствии с греческой этимологией, ошибки единичны (помечены *): ақналда́рz-

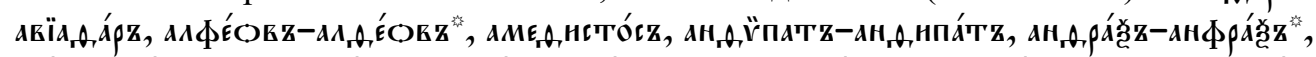

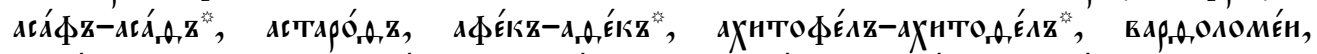

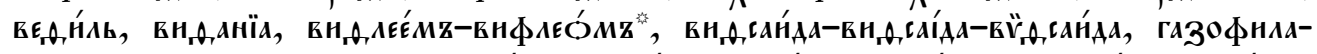

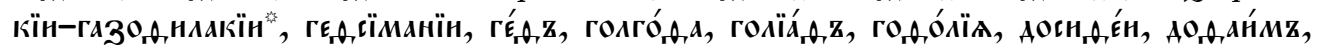
елїсакев, в, елнса́фz-елнса́,

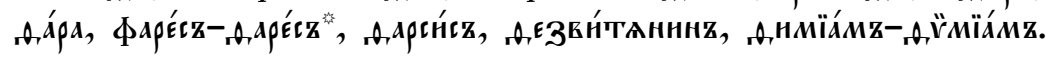




\section{7. $3=S$}

$\mathrm{B}$ современном церковнославянском $\mathrm{S}$ регулярно пишется в определенных сло-

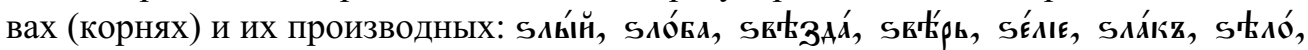

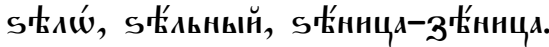

В Острожской Библии $\mathrm{S}$ употребляется в следующих случаях:

1) довольно регулярно вместо 3 , которое чередуется с Г/Ж по результа-

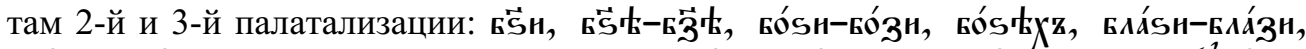

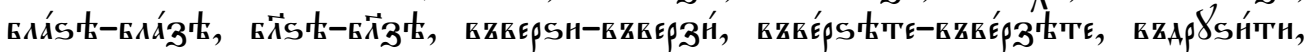

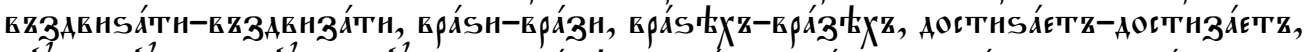

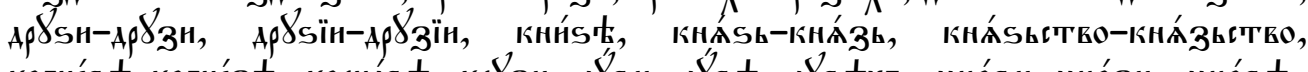

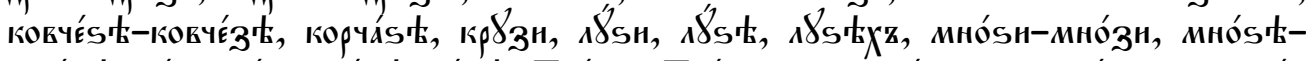

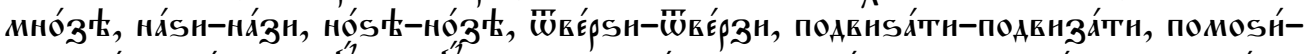

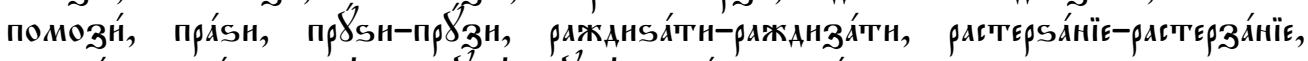

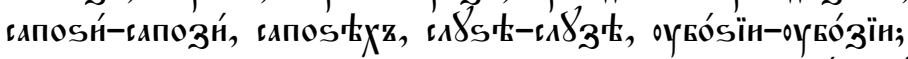

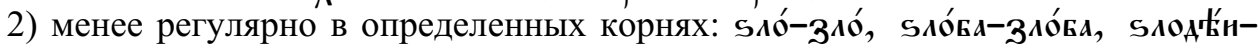

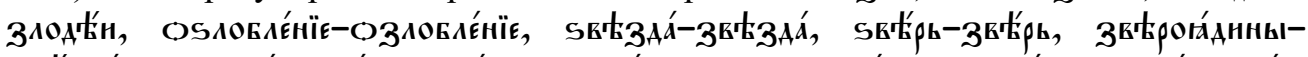

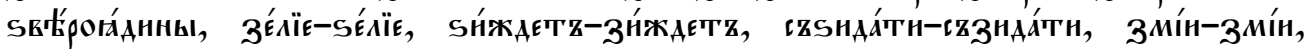

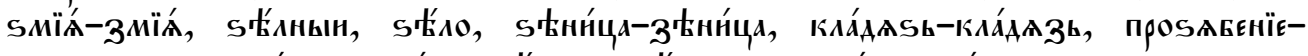

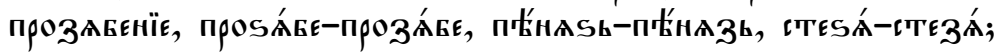

3 в в единичных случаях вместо более обычного 3 (редкие случаи помечены *):

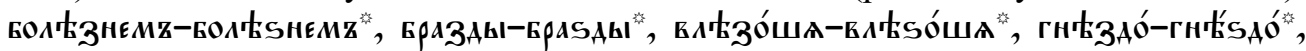

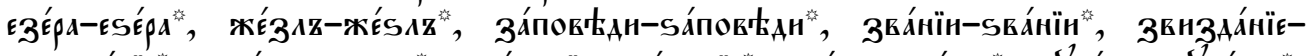

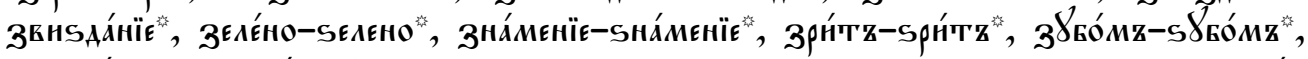

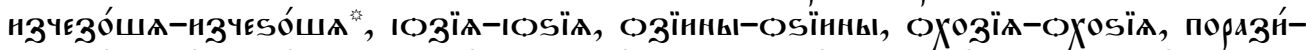

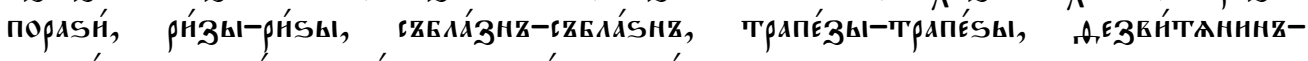

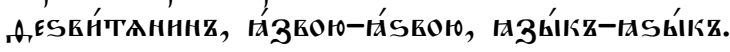

\section{5. Титло и выносные буквы.}

В древнейшей кириллице надстрочные знаки употреблялись крайне редко: тит-

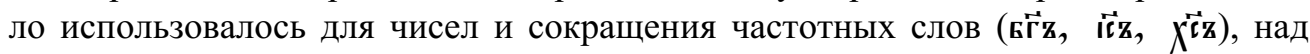
гласной в начале слога иногда ставилась точка, знаки ударения не применялись. В русской кириллице употребление надстрочных знаков существенно расширилось: появились выносные буквы (буквотитла), паерок, покрытие, знаки ударения и придыхания стали употребляться часто, хотя нерегулярно [Карский 1979]. Все это создало дополнительные возможности для орфографического разнобоя.

\section{1. Титло}

В Острожской Библии титло и некоторые буквотитла употребляются для частотных слов и корней, обычно сакральных: áгі்

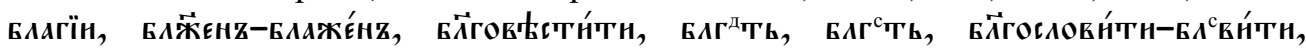




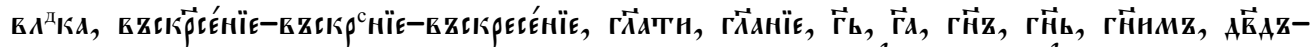

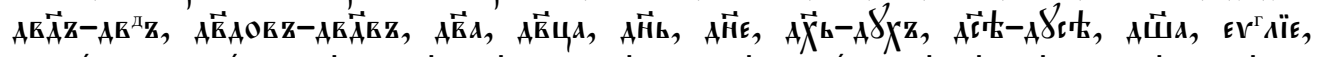

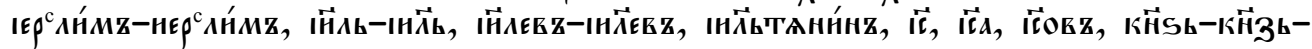

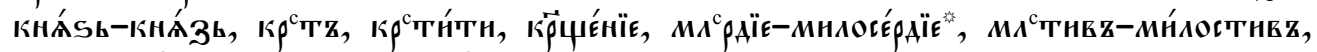

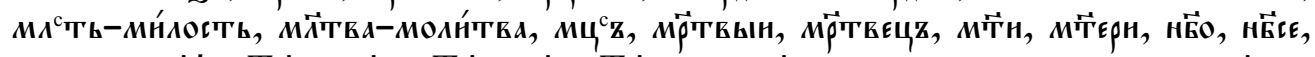

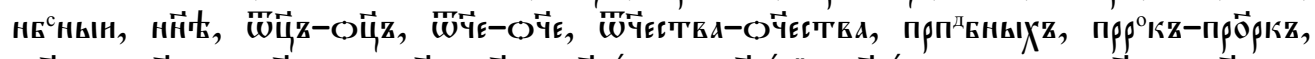

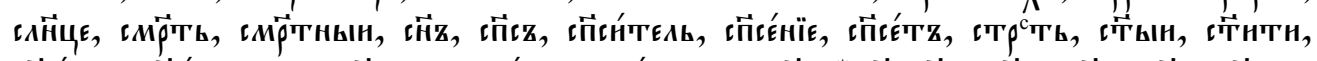

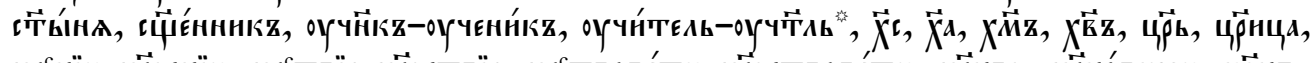

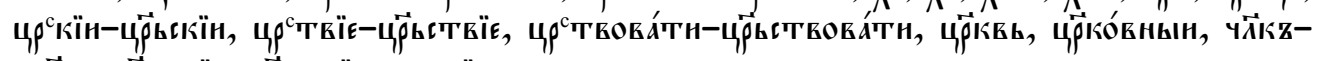

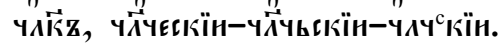

Список слов и корней под титлом в основном совпадает с современной нормой, однако здесь не проводится различие между сакральным и обычным употреблени-

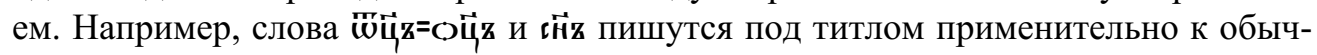
ным людям, тогда как в современном церковнославянском в этом случае они пишутся без титла.

\section{2. Выноснье буквы}

Выносные буквы (буквотитла) использовались как способ сокращения слов при нехватке места в строке. Поскольку выносная буква ставится над предыдущей буквой, а не после нее, слово становится короче по горизонтали, но немного выше по вертикали. Например, написание ко $\boldsymbol{м \varepsilon}^{\mathrm{T}}$ vs. козмєтz занимает 4 позиции vs. 7,

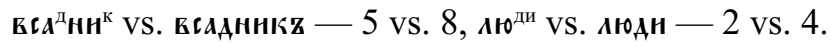

Выносные буквы создают массу проблем и являются источником ошибок. То, что легко делается в рукописном тексте, создает большие трудности при печати, поскольку поставить выносную букву на нужное место не всегда возможно. Во-первых, есть высокие буквы Ғ 8 , над которыми физически невозможно поставить надстрочный знак, поэтому его ставят над предыдущей буквой, то есть еще левее от нормальной позиции. Во-вторых, выносные буквы часто сдвигаются со своего места по непонятным причинам или в результате неаккуратности наборщика. В результате появляются слова с неправильным порядком букв, которые можно прочитать, только если передвинуть букву на пра-

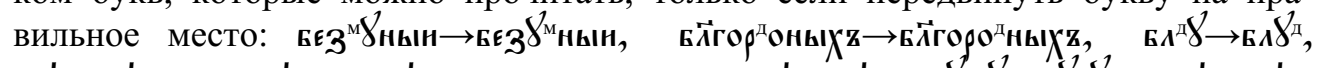

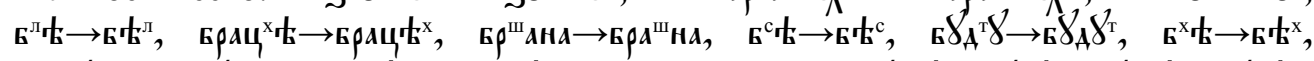

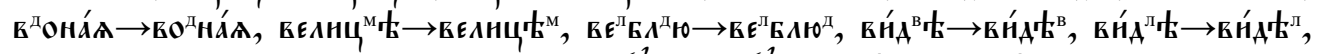

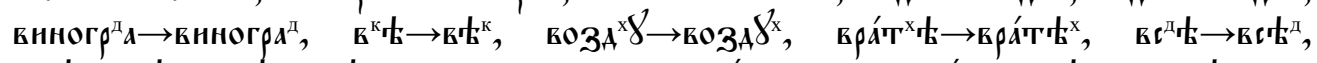

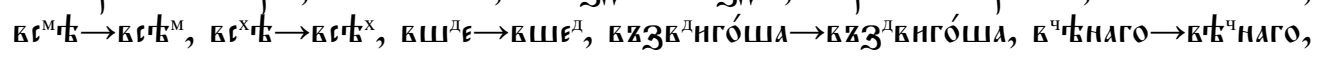

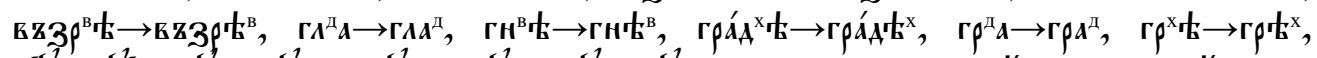

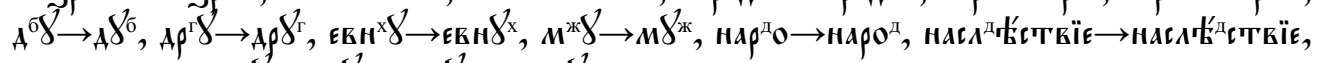

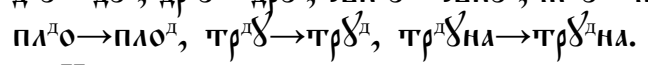

Человек может легко прочитать слово с неправильным порядком букв, но программа этого сделать не сможет, если ей не указать специально. Поскольку изначально неизвестно, что буквы переставлены и где именно, программа будет 
вынуждена перебирать весь словарь, чтобы найти подходящий вариант, и не факт, что этот вариант будет правильным.

Выносные буквы открывают возможность для орфографического разнобоя: любая согласная перед согласной или на конце слова может быть записана как выносная. Дополнительную путаницу вносит немой $\mathrm{b}$, который часто пишется не только в конце слова, но и в середине, а также может заменяться на надстрочный знак (паерок). В результате такой орфографической свободы в тексте Острожской Библии некоторые слова могут иметь более десятка (!) вариантов написания (если

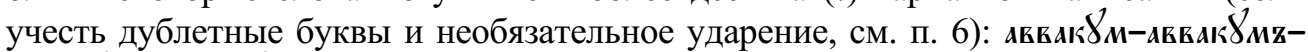

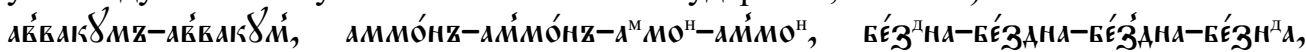

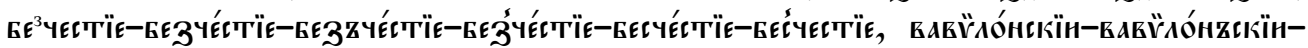

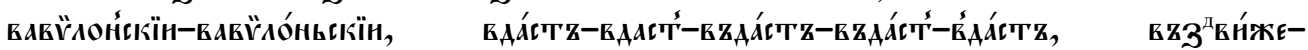

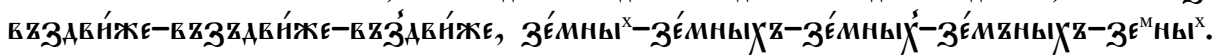

Выносные буквы иногда употребляются и в других случаях. Например, вынос-

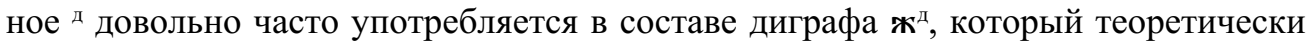
может обозначать специфическое сочетание [ж’дж'], являющееся звонким коррелятом $\varkappa_{\xi}=\left[u^{\prime} y^{\prime}\right]$, хотя на основании графики определить его фонетическое значение невозможно. Примеры (знак означает фонетически близкие варианты): БА

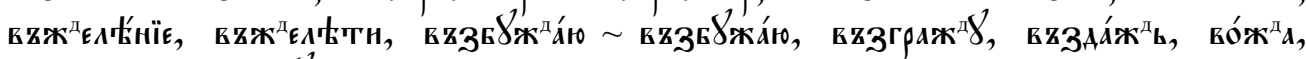

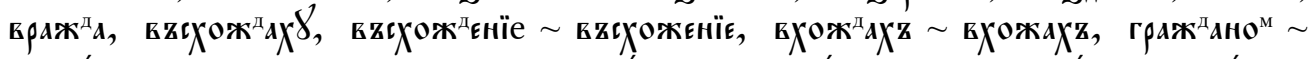

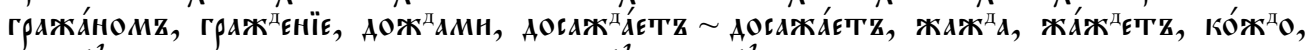

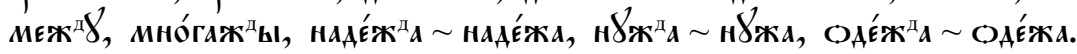

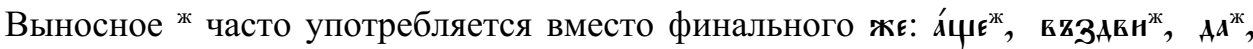

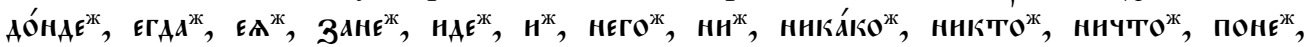
та́кко

Выносное ${ }^{\text {г } и н о г д а ~ у п о т р е б л я е т с я ~ в м е с т о ~ ф и н а л ь н о г о ~ г о ~(а д ъ е к т и в н а я ~ ф л е к с и я): ~}$

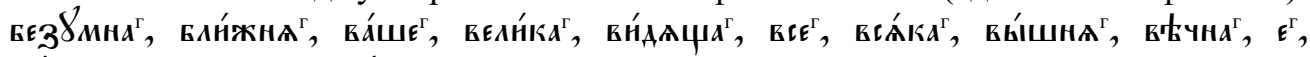

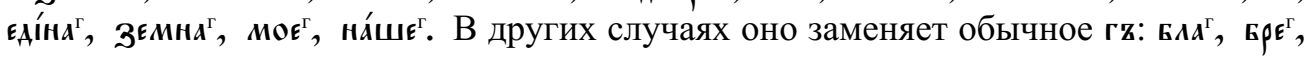

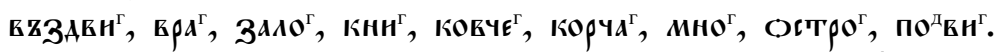

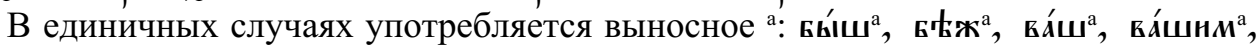

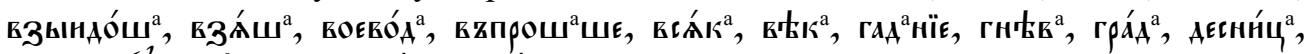

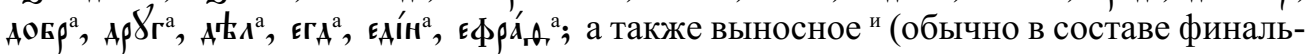
НОГО ди): кЕЕє

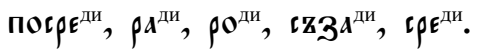

В современном церковнославянском буквотитла используются только в соста-

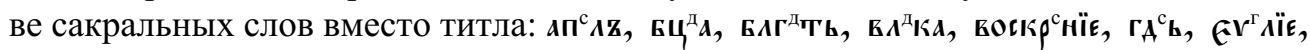

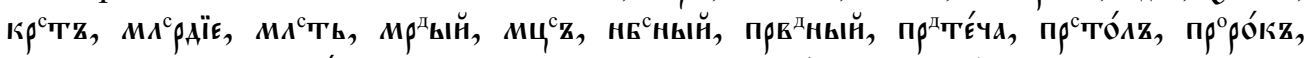

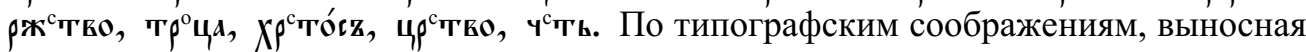
буква обычно не ставится над начальной буквой слова, а сдвигается вправо, поэ-

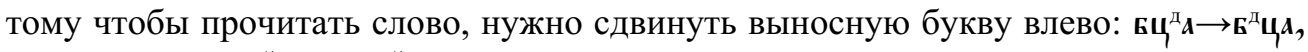

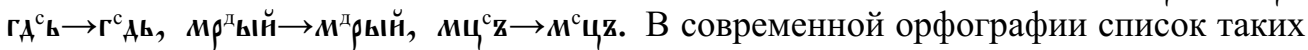
слов конечен и эту проблему можно легко решить словарно, а не алгоритмически. 


\section{6. Ударение и придыхание}

Знаки ударения и придыхания не употреблялись в древнейшей кириллице и были введены позже как подражание греческому письму [Карский 1979]. В греческом было три знака ударения ( ’ ) и два знака придыхания, хотя фонетическое различие между ними было утрачено задолго до создания славянской письменности: все три ударения звучали одинаково, а придыхание не произносилось. В славянских языках ударение имело смыслоразличительный характер, а придыхание оказалось чисто графическим знаком, не несущем никакого смысла. В греческом придыхание ставилось в начале слова и тем самым обозначало словесную границу в слитном письме, а в славянском оно нередко ставилось внутри слова и обозначало слоговую границу, которая и так очевидна из контекста.

\section{1. Ударение}

В современном церковнославянском основным знаком ударения является оксия ( ), которая регулярно заменяется на варию (’) в конце фонетического слова, согласно правилам греческого языка. Камора (^) употребляется для различения форм единственного vs. множественного/двойственного числа (клаги́мz vs. благи̂мz,

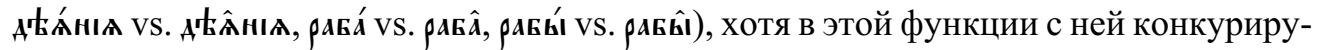
ет различие Е-С и О-G) (см. п. 4).

В Острожской Библии ударение употребляется крайне непоследовательно. Одно и то же слово может писаться с ударением или без него, ударение может стоять

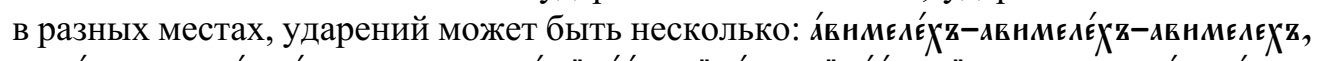

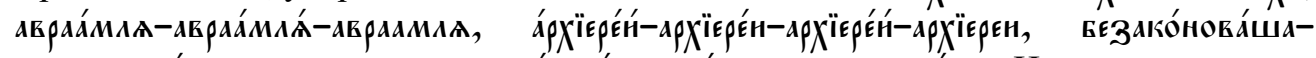

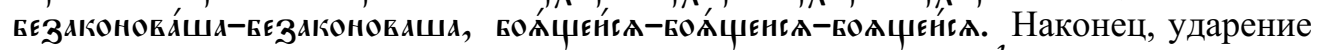
может быть сдвинуто со своего места из-за высоких букв (Ғ 8) или типографской небрежности, в результате чего ударение фактически оказывается над согласной (!): кез Зُ Мнын-кез на, БОАЕТZ-Б

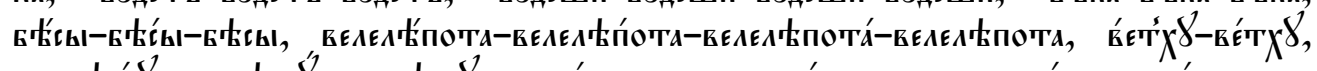

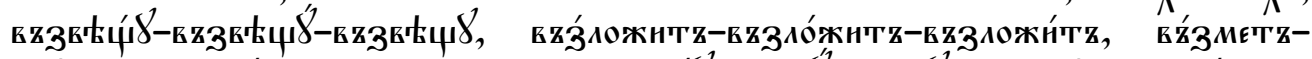

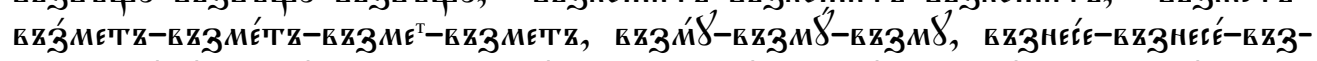

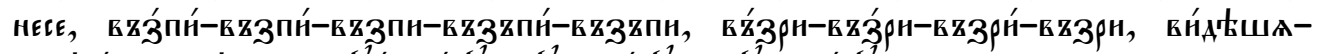

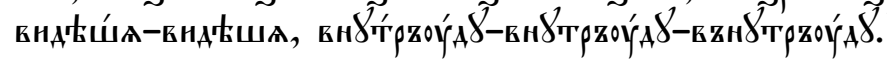

Возможно, некоторые случаи сдвига ударения имеют под собой фонетическое основание, но при такой орфографической свободе их невозможно отличить от ошибок набора.

Основным знаком ударения также является оксия ('), которая регулярно заменяется на варию (') в конце фонетического слова. В некоторых односложных/служебных словах вместо оксии также употребляется камора $\left(^{\wedge}\right)$, которая обычно ставится

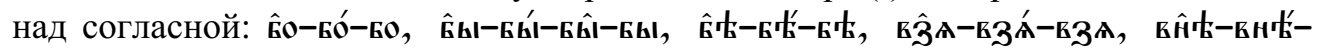

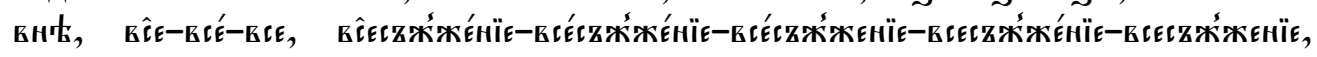




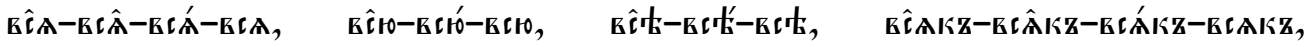

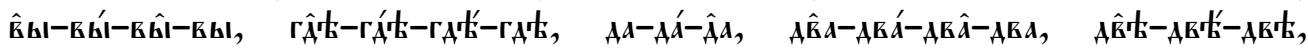

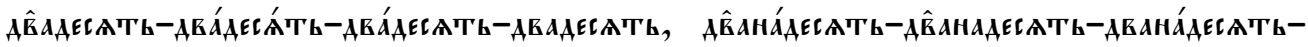

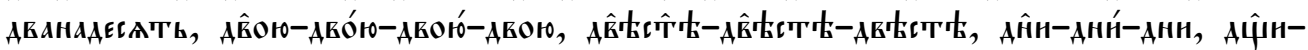

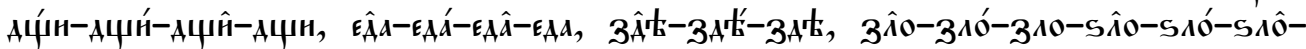

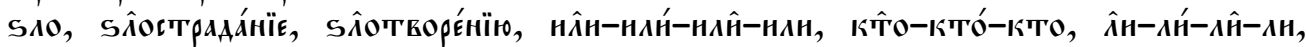

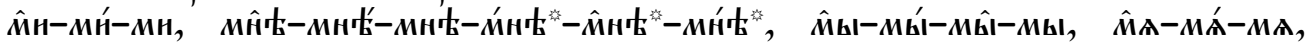

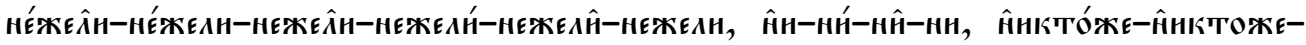

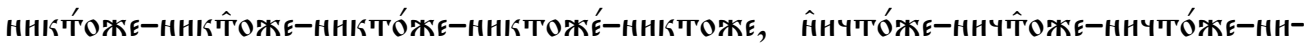

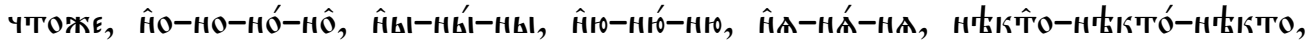

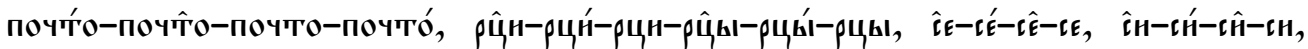

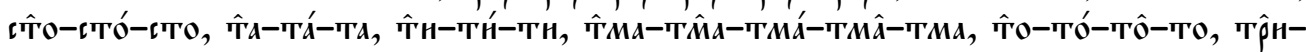

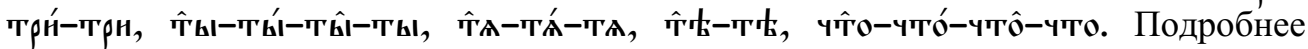
об употреблении каморы в данных случаях см. [Кусмауль 2017].

Поскольку ударение в Острожской Библии употребляется крайне нерегулярно, то с точки зрения морфологического анализатора придется его просто игнорировать. При этом мы теряем возможность различить некоторые омонимы (коди́ vs. ко́ды), но это небольшая потеря на общем фоне.

\section{2. Придыхание}

В современном церковнославянском придыхание автоматически ставится над начальной гласной слова и не имеет смыслоразличительной функции.

В Острожской Библии придыхание регулярно ставится над начальной гласной слова, если только оно не пропущено по типографской небрежности. Кроме того, придыхание иногда ставится над начальной гласной слога внутри слова, особенно в следующих случаях:

1) довольно часто над гласной в начале слога в иностранных словах: Аåрóнz,

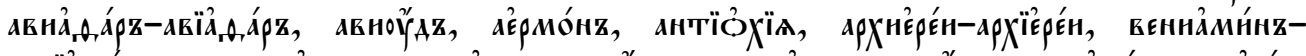

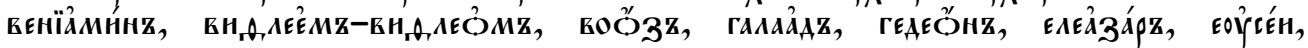

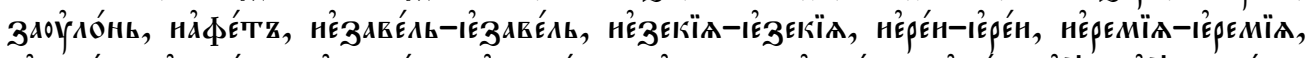

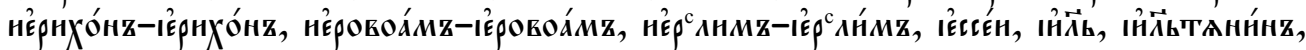

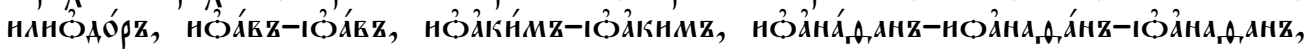

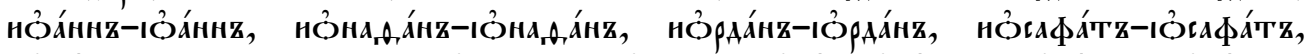

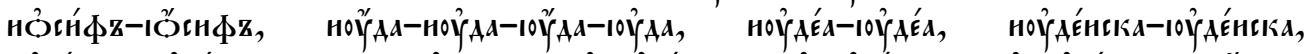

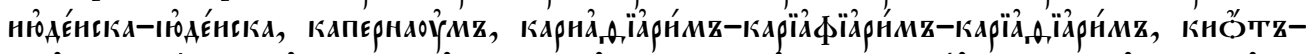

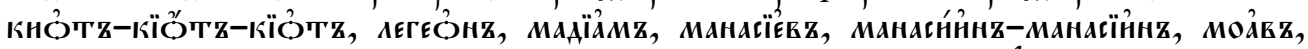

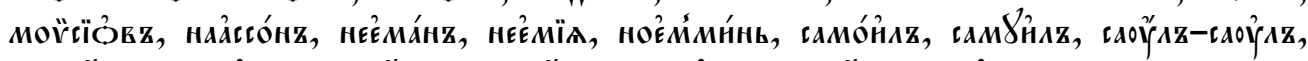

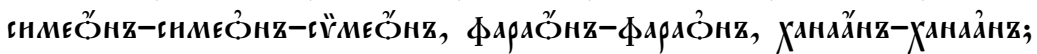

2) довольно часто над гласной в начале корня в сложных словах: кйгоб̆қразєнz,

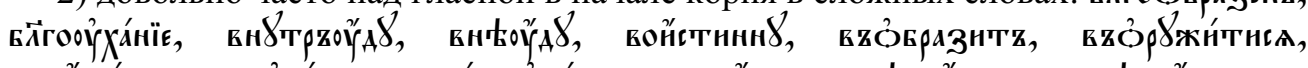

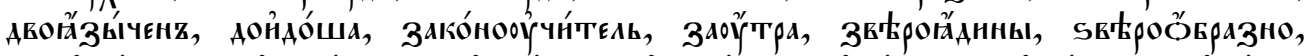

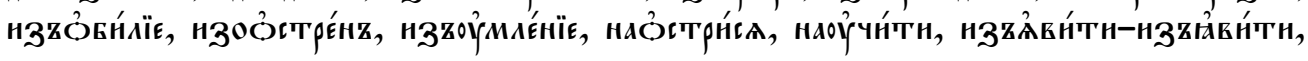




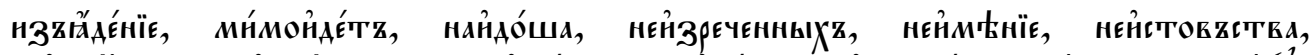

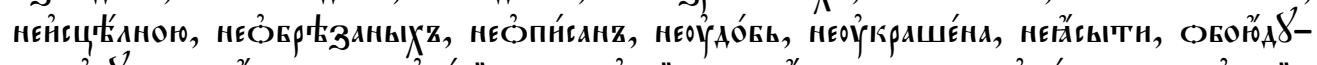

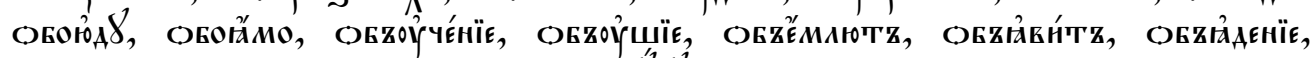

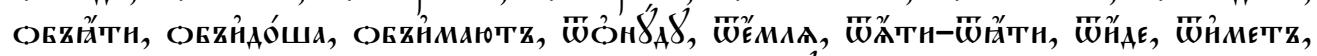

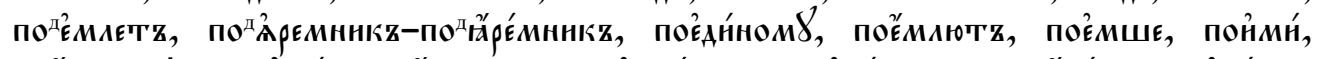

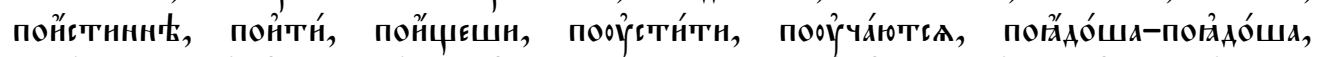

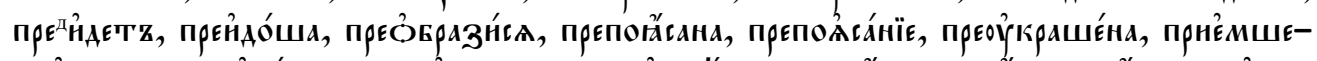

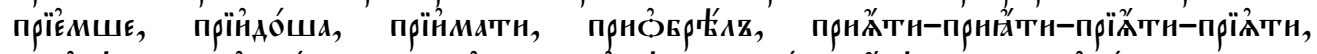

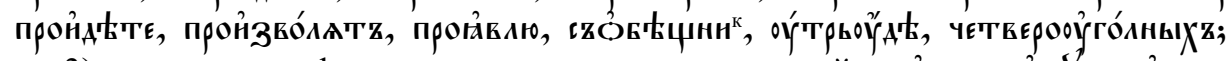

3) регулярно во флексиях некоторых местоимений: мое́го, мое́мХ, мое́мz, мое́ю,

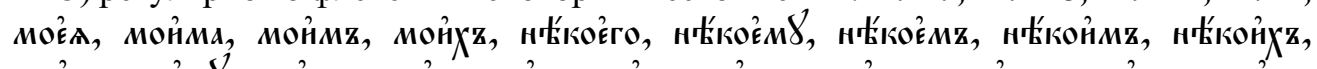

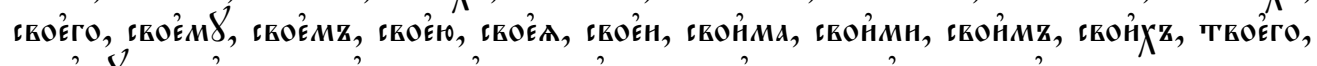

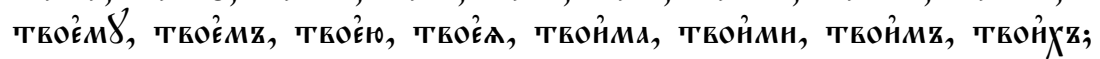

4) иногда в определенных глагольных флексиях и суффиксах причастий: АА́̃тє,

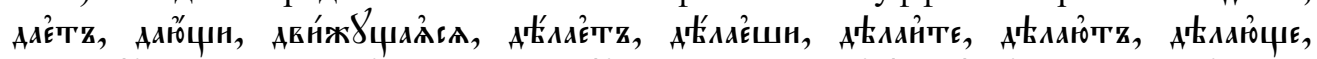

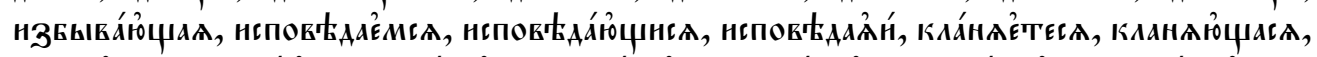

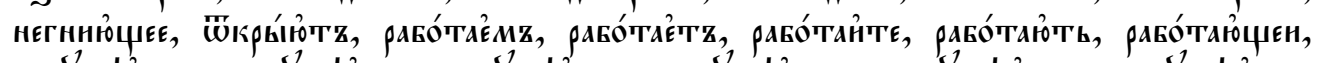

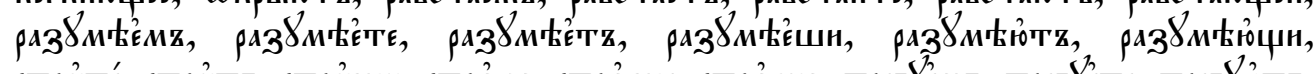

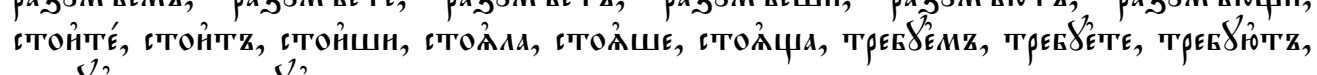

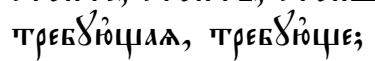

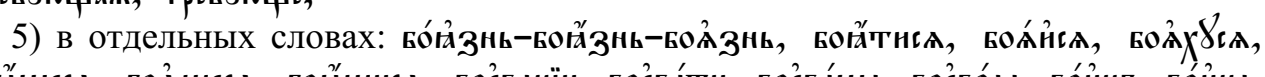

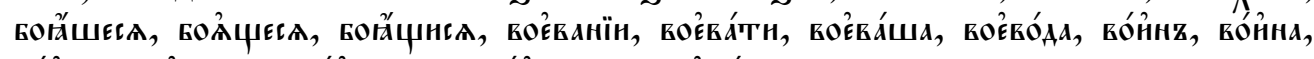

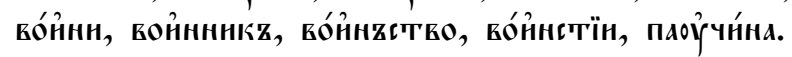

Придыхание внутри слова почти всегда необязательно и может отсутствовать. Достаточно регулярно оно ставится только над буквами Oy, O (реже над I: ким образом, здесь диакритика становится как бы частью буквы. Это создает дополнительное визуальное противопоставление между «автономными» Оy, О, которые могут образовывать самостоятельный слог, и «связанными» $\mathbf{g}, \mathrm{O}$, которые всегда стоят после согласной.

\section{7. Отдельные особенности.}

Перечислим кратко другие орфографические особенности Острожской Библии:

\section{1. Отсутствие буквы Й}

Буква Й исторически представляет собой сочетание И с надстрочным знаком «краткая». В Острожской Библии этот знак употребляется крайне редко и непо-

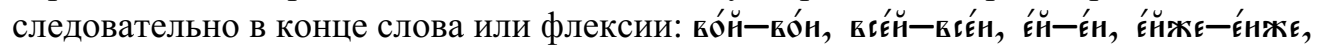

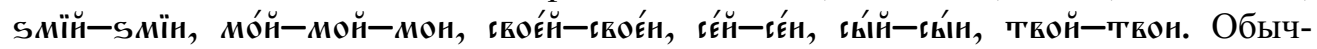
но краткость И никак не обозначается, что порождает множество грамматических омонимов (мой=мон, край=кран). Это создает огромную проблему для морфологического анализа: приходится переделывать всю систему флексий и часть словаря. 


\section{2. Архаичные и южнославянские написания}

\subsection{1. $P / Л+Ъ / b$}

В некоторых корнях достаточно часто пишутся архаичные/южнославянские сочетания $\mathrm{P} / Л+\mathrm{b} / \mathrm{Ь}$ или Ъ/Ь+Р/Л вместо более обычных русских ЕР, ОР, ОЛ: кл́́кz,

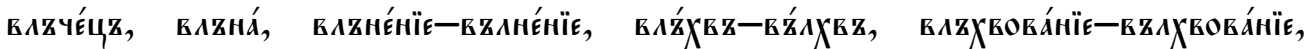

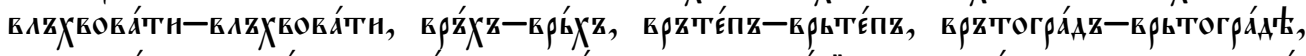

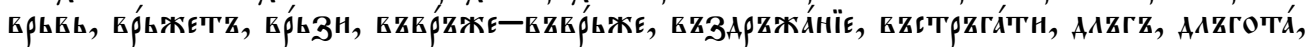

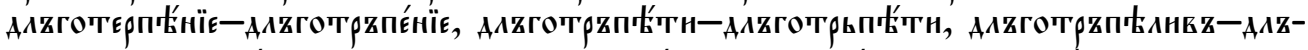

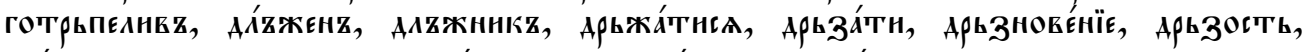

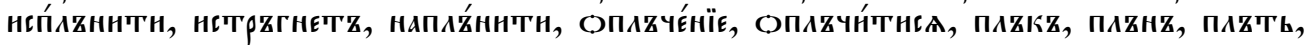

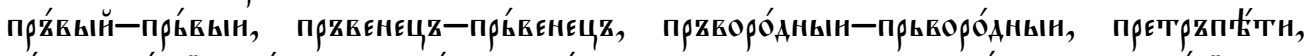
пр́ьсн, при́скї̈, пр́сстень, при́стz, при́сть, растрдгнетz, растрzза́тн, растрzза́нїє.

\subsection{2. Начальные ВЬ, СЬ}

В приставках кz, къз/кzс, сқ часто пишется Ђ независимо от произношения, которое может быть [о] или нуль, причем точно это установить невозможно:

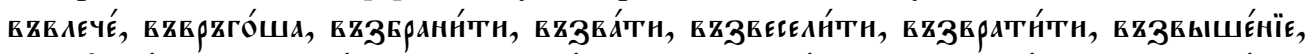

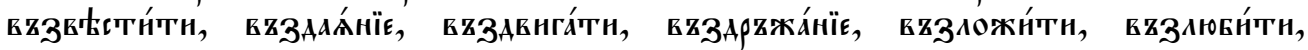

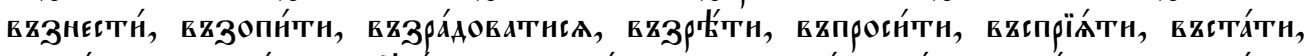

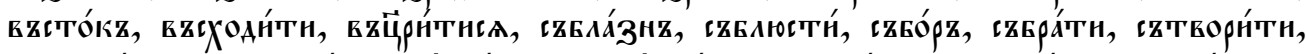

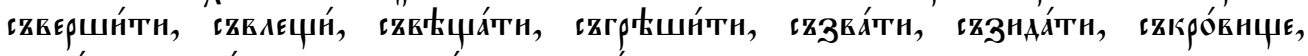
гвкрйтн, гвста́внтн, гвтвори́тн, гвчєта́тн.

Эта орфографическая условность (кz, $\mathbf{\imath}=\mathbf{k} \boldsymbol{0}, \mathfrak{c o})$ настолько сильна, что иногда проникает даже в слова без приставок: кұдо́ю, кұєка́тн, кұєко́дамz, кұми́, кұо́зzв, ‘zEóro.

\subsection{3. А вместо А после гласной}

Иногда по болгарскому образцу вместо $\mathbf{A}$ пишется А после гласных А, O, реже после $\mathrm{b}, \mathrm{Oy.} \mathrm{Обычно} \mathrm{это} \mathrm{происходит} \mathrm{во} \mathrm{флексиях,} \mathrm{реже} \mathrm{в} \mathrm{суффиксах} \mathrm{и} \mathrm{основах.}$ Примеры:

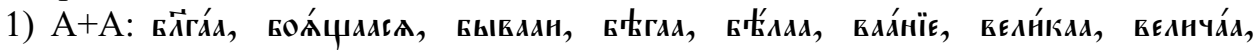

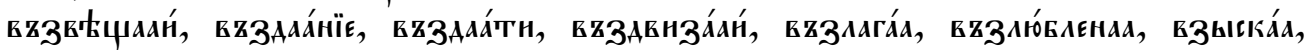

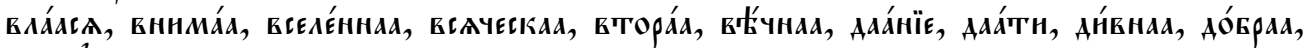

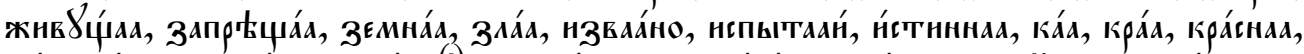

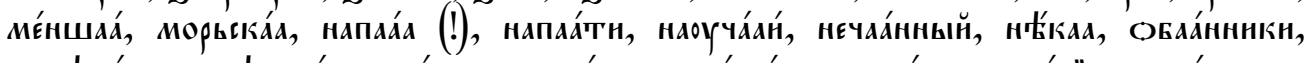

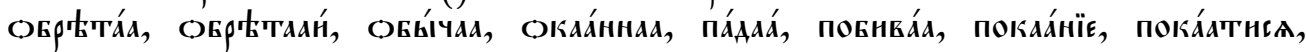

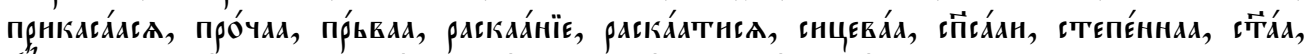

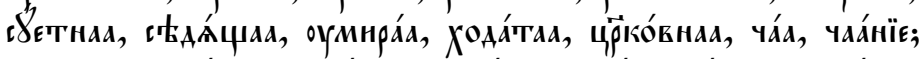

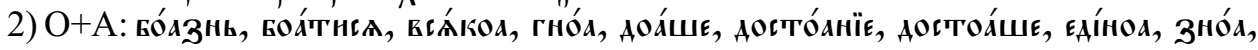

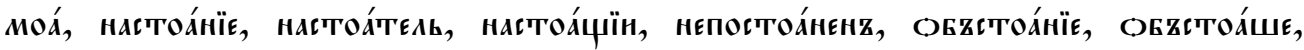




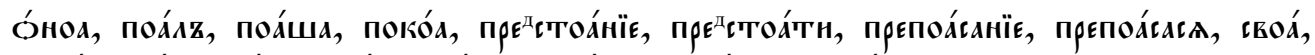
твоа́, тоа́, гтоа́, гтоли́, гтоа́ло, гтоа́нїє, гтоа́тн, оукоа́тнса;

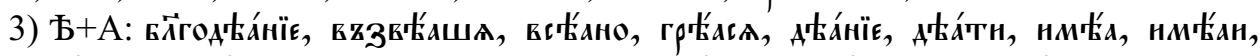

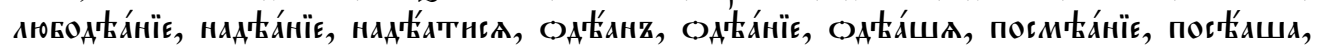

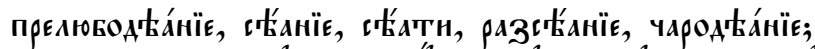

4) Уூ+А: кег"а овУа́єтт, ов paа $\gamma_{\text {aca, трев }} \gamma_{\text {a. }}$

Замена А на А также встречается после Е, І в славянских словах, но это явление наблюдается и современном церковнославянском, хотя значительно реже.

\section{9. Заключение}

Анализ орфографических особенностей Острожской Библии приводит нас к следующему выводу. Морфологический анализатор для церковнославянского языка требует существенной переделки, чтобы он мог обрабатывать тексты в старой орфографии, особенно с учетом царящей там орфографической свободы. Можно выделить следующие направления работы:

1) Применять более «агрессивные» методы унификации исходных написаний, чтобы свести вместе все возможные орфографические варианты, даже если это приведет к некоторой потере информации.

2) Научиться работать с неполной и неточной информацией, сделать нечеткий поиск в словаре и грамматических таблицах.

3) Ввести в словарь дополнительные варианты написания, которые невозможно вычислить алгоритмическими методами.

\section{Литература}

Алипий (Гаманович). Грамматика церковно-славянскаго языка. Jordanville (N. Y.), 1964.

Плетнева А.А., Кравецкий А.Г. Церковнославянский язык. 4-е доп. изд. М., 2006.

Поляков A.E. Корпус церковнославянских текстов: проблемы орфографии и грамматики // Przegląd wschodnioeuropejski. V. 1, 2014. S. 245-254. URL: http:// www.ruslang.ru/doc/church-slav/conf4/05-polyakov.pdf.

Поляков A. E. Грамматический словарь церковнославянского языка (по материалам корпуса). // Труды международной конференции «Корпусная лингвистика 2017». СПб., 2017. С. 295-298.

Добрушина Е.P., Кравецкий А.Г., Поляков А.Е. Корпус и частотный грамматический корпусный словарь церковнославянского языка в составе Национального корпуса русского языка // Национальный корпус русского языка: 10 лет проекту. Труды Института русского языка им. В. В. Виноградова. Вып. 6. М., 2015. С. 116141. 
Острожская Библия (факсимиле). URL: http://www.vechnoe.info/bible/pdf, http:// samstar-biblio.ucoz.ru/load/46-1-0-84.

Острожская Библия: современный набор с параллельным переводом на украинский язык. Подготовил Рафаил (Роман) Торконяк. Львов, 2006. URL: http://www. vechnoe.info/bible/ostrog-bible-ukranian/view.

Church Slavonic typography in Unicode. URL: http://www.unicode.org/notes/tn41/.

Кириллица в Юникоде. URL: https://ru.wikipedia.org/wiki/Кириллица_в_Юникоде.

Карский Е.Ф. Славянская кирилловская палеография. М.: Наука, 1979. ХІХ, $494 \mathrm{c}$.

Каверина В. В. Становление русской орфографии в XVII-XIX вв. : правописный узус и кодификация / дисс. ... докт. фил. наук. М., 2010. 436 c. URL: http://www. ruslang.ru/doc/autoref/kaverina.pdf

Кусмауль С.М. Книжная справа 40-х годов XVII века // Slověne. 2014. №1. C. $72-101$.

Кусмауль С.М. Эволюция функций знака каморы в богослужебных изданиях кон. XVI - перв. пол. XVII в. // Вестник ПСТГУ. Серия III: Филология. 2017. Вып. 51. С. 21-47. URL: http://pstgu.ru/download/1498120889.2_Kusmaul_21-47.pdf.

\author{
A. E. Polyakov \\ (Russia, Moscow) \\ pollex@mail.ru
}

\title{
SPELLING OF THE OSTROG BIBLE IN CONTEXT OF THE CHURCH SLAVONIC CORPUS
}

Modern Church Slavonic spelling is fairly standardized and defines the rules for letters and diacritics, abbreviations (titlo and letter-titlos), word separation, spelling of word forms and distinction of homonyms. This standard helped us to create a grammar dictionary and morphological analyzer for Church Slavonic (http://dic.feb-web.ru/slavonic/dicgram/index.htm), which is used in the corpus of Church Slavonic texts (http://ruscorpora. $\mathrm{ru} / \mathrm{search}$-orthlib.html). The Ostrog Bible (1581) is the first complete edition of the Bible in Church Slavonic and should be included into the corpus, but a number of problems have occured. The spelling of this edition deviates from the modern standard and is extremely irregular and unstable. This article analyzes the spelling peculiarities of the Ostrog Bible and the feasibility of its automatic morphological analysis. Special attention is paid to duplicate letters and other graphic symbols which generate a lot of spelling variations for a particular word. We conclude that the morphological analyzer should be significantly reworked in order to process the old spelling, and determine the directions of further work.

Keywords: Church Slavonic, spelling, corpus linguistics, automatic morphological analysis 


\section{References}

Alipii (Gamanovich). Grammatika tserkovno-slavyanskago yazyka. [Grammar of Church Slavonic] Jordanville (N. Y.), 1964. (In Russ.)

Pletneva A.A., Kravetskii A. G. Tserkovnoslavyanskii yazyk. [Church Slavonic] 4th aug. ed. Moscow, 2006. (In Russ.)

Polyakov A.E. [Corpus of Church Slavonic texts: problems of spelling and grammar]. Przeglad wschodnioeuropejski. V. 1, 2014. pp. 245-254. Available at: http://www. ruslang.ru/doc/church-slav/conf4/05-polyakov.pdf. (In Russ.)

Polyakov A.E. [Grammatical dictionary of Church Slavonic (corpus-based)]. Trudy mezhdunarodnoi konferentsii «Korpusnaya lingvistika-2017» [Proceedings of the International Conference "Corpus Linguistics-2017"]. St. Petersburg, 2017. pp. 295298. (In Russ.)

Dobrushina E. R., Kravetskii A. G., Polyakov A. E. [Corpus and frequency grammatical dictionary of Church Slavonic within the National corpus of Russian]. Trudy Instituta russkogo yazyka im. V.V. Vinogradova [Proceedings of the V.V. Vinogradov Russian Language Institute]. 2015, no. 6, pp. 116-141.

Ostrog Bible (facsimile). Available at: http://www.vechnoe.info/bible/pdf, http:// samstar-biblio.ucoz.ru/load/46-1-0-84.

Ostrozhskaya Bibliya: sovremennyi nabor s parallel'nym perevodom na ukrainskii yazyk [Ostrog Bible: modern typesetting with parallel Ukrainian translation] Prepared by Rafail (Roman) Torkonyak. L'vov, 2006. Available at: http://www.vechnoe.info/bible/ ostrog-bible-ukranian/view.

Church Slavonic typography in Unicode. Available at http://www.unicode.org/notes/ tn $41 /$.

Cyrillic script in Unicode. Available at: https://en.wikipedia.org/wiki/Cyrillic_script_ in_Unicode.

Karskii E. F. Slavyanskaya kirillovskaya paleografiya [Slavic Cyrillic paleography]. Moscow, Nauka Publ., 1979. XIX, 494 p. (In Russ.)

Kaverina V.V. Stanovlenie russkoi orfografii v XVII-XIX vv.: pravopisnyi uzus $i$ kodifikatsiya. Diss. dokt. fil. nauk. [Formation of Russian spelling in 17th-19th centuries: spelling usage and codification. Dr. phil. sci. diss.] Moscow, 2010. 436 p. Available at: http://www.ruslang.ru/doc/autoref/kaverina.pdf (In Russ.)

Kusmaul' S. M. [Book Correction in the 40s of the 17th Century]. Slověne. 2014. № 1. pp. 72-101. (In Russ.)

Kusmaul' S.M. [Evolution of the functions of the kamora sign in liturgical books from the late 16th to the first half of the 17th centuries]. Vestnik PSTGU. Ser. III: Filologiya. Moscow, 2017. Vyp. 51. pp. 21-47. Available at: http://pstgu.ru/ download/1498120889.2_Kusmaul_21-47.pdf. 